\title{
RETHINKING THE TERRITORIAL PACT IN THE CONTEXT OF EUROPEAN TERRITORIAL COHESION
}

\author{
Irina SAGHIN ${ }^{1)}$, Gabrie/ PASCARIU ${ }^{2)}$, Daniela Rodica STOIAN ${ }^{11}$, \\ Ilinca-Valentina STOICA ${ }^{1)}$, Daniela ZAMFIR ${ }^{1)}$ \\ 1) University of Bucharest, Interdisciplinary Centre for Advanced Research on \\ Territorial Dynamics, ${ }^{2) " I o n ~ M i n c u " ~ U n i v e r s i t y ~ o f ~ A r c h i t e c t u r e ~ a n d ~ U r b a n i s m, ~}$ \\ Bucharest, Romania
}

\begin{abstract}
The authors argue through this paper, the importance of rethinking the recently abandoned tools that can be reactivated in times of crisis. EU 2020 Strategy and other EU documents create a favorable frame in order to achieve the priorities set by reconsidering the territorial pact concept. Recent documents define the partnership agreement concept, which seems to be more rigid and less flexible than the territorial pact. Having as a starter point Romania's specifics, there are individualized 10 thematic territorial pacts and 8 global pacts. They must generate territorial synergies capable of ensuring the coherence between regions, states and the European Union as a whole.
\end{abstract}

Keywords: territorial pact, partnership agreement, EU 2020 Strategy, territorial cohesion, sectoral/thematic pact, global pact.

\section{Introduction}

Europe is undergoing a period of major transformations caused by the persistence, scale and impact of the economic and financial crisis. As a direct consequence in the spatial plan, a profound reshuffle of the territorial structures can be distinguished from local to global levels (Kiss 2011). Optimistic forecasts encounter certainty and recent developments show that there is not systematic failure in capitalism (Harvey 2010) and that this is unpredictable in duration. Therefore, searching for solutions, one of the current questions relates to the direct and indirect potential that could have a proper spatial development upon mitigating the crisis. In the context of the reinforcement necessity for the role of states in the development process, getting back its fundamental function of regulator (Uzunov 2012), there is also a reconsideration of endogenous development, which involves additional security among space actors of a state union, of any State or region. Recent evolution show "re-teritorialization of the state" and "the re-scaling of state power" tendencies (Jones and Jessop 2010, p.1137), along with a tendency to increase the role played by the networks of territorial actors.

The context of territorial development is quite complex and does not seem to guarantee an evolution that brings, with certainty, sustainable development. Even though after 2010 documents of great importance for European territorial development were defined and approved by 2020 (EU 2020 Strategy and the Territorial Agenda) without a coherent action at lower levels where there is no possibility to increase the response capacity of local and regional communities to the new challenges arising from the current crisis. In addition to the many tools and sets of austerity measures, an essential step should be the conscious assumption of responsibility for actions to implement joint projects. These can cover both sectorial and global aspects. 
European policies have largely followed a path marked out by excessive neo-liberalism (Hadjimichalis 2011), which promoted a macro-economic planning from the top down and a dogmatic view, according to which the only process that can solve territorial disparities is competition, and in its subtle form, competitiveness. As not all European regions and cities can be competitive, then those that are will increase the competitiveness through cooperation with the others. If this process would also have a solid feedback, to be more precise some of the extra return value of increasing competitiveness by cooperating with regions and cities, then we could say that the mechanism works. However, this operation should not be considered solidarity (sometimes with humiliating connotations), but simply an act of territorial inherent regulation for an integrated European development process (lanoş 2012).

To the current situation there is to be added one thing, emerged from the recent history of new states coming out from communist system, that didn't know to negotiate their entry into the European structures. Their lack of cohesion and the existence of individualism, emerged from the desire of each state to be better placed than others in matters of competition launched by the EU and it has been observed since the early 2000s (Kulcsar 2003). Therefore, taking into account that from an economic and social point of view there is to discuss about not only one single Europe but "many Europes" (Agnew 2001), there shall be required not only to develop a strategy, but a set of appropriate strategies for each group of countries or regions.

In this complexity, it is useful the rediscovery of tools and methods that have played a more or less important role in some recent history on territorial development. These tools include the territorial pact, appeared as a continuation of formalized cooperation between several local institutions and organizations. This formalizing occurred in early ' 90 s in Italy (forms of cooperation have emerged since the early '70s), and later in Germany (Picchieri 2002). It appears that the formalization of the territorial pact was based on an idea of combining central and local policies (De Rita and Bonomi 1998), so that community projects would have been financed from government funds. Procedures have been regulated since 1995, an essential role being played by 'Comitato Interministeriale per la Programmazione Economica'. In most of the cases, the territorial pacts in Italy focused on local development with industrial districts in the center (Clerici, 2004). The current complexity of the territorial reality demands flexibility in organizing the production process which implies a high interconnexion, a more complicated network between all the actors (Grosjean and Crevoisier 2003).

The territorial pact concept is more complex than the one frequently used to offer support to institutions by different actors in the socio-economic, financial, cultural life. It is known that the operation of every institution implies an agreement, a pact between all these actors. They accept the rules set by the institutions, although sometimes they are in competition. Therefore, a pact to support the institutions is created, one that regulates the socio-economic processes (Schneider 2006). The teritorial pact can be seen as a part of the integrated development model at a regional and loca scale, sustaining the endogeneous development (Christofakis 2001).

The most important success represents the pacts focused on solving social problems, especially those relating to territorial employment (Elisei 2012). Even the European Commission approved the European Employment Pact in 1996, insisting on the idea of multiplying effects in using Structural Funds for territorial development.

As globalization has positive effects on local and regional economies, the territorial pact by reporting to the local, rarely regional, but apparently its numerous bureaucratic elements, was abandoned. Now that globalization has shown some limitations, returning to a different 
territorial pact seems to be a good way of strengthening the regions and their subunits.

\section{The current European context of 'reinventing the territorial pact'}

At European level, territorial development policies are facing contradictory elements caused by the transition from a planning period (2007-2013) to another (2014-2020), given the conditions of a crisis that seems to be spreading throughout the $2^{\text {nd }}$ decade of this century. Many documents, policies and thus instruments have been designed as a support tool to ensure territorial development and economic convergence at European level. In this regard, it is relevant the EU 2020 Strategy, launched in November 2009 and discussed in the European Parliament, the Council of Ministers and in other forums, in early 2010 (it was adopted in June 2010 at Brussels).

The main priorities of the strategy aims smart growth, by supporting the process of innovation and knowledge, sustainable growth, with an emphasis on resource efficiency and inclusive growth, by increasing labor force to ensure economic, social and territorial cohesion. These priorities are joined by seven programs to stimulate progress initiative "A European structure innovation", "Youth on the Move", "A Digital Agenda for Europe", "Efficient Europe in terms of resource", "An industrial policy for the globalization era", "An Agenda for new skills and jobs", "European platform against poverty". What the EU wants, through these initiatives, is to strengthen economic governance in order to end the crisis, governance that clearly needs a consistent and coherent regional support development. The implementation of these strategies will represent between others an important progress in achieving territorial cohesion at different levels. Acoording to some scientists, territorial cohesion is one of the concepts with a high innovative potential concerning European Commission purposed policies (Camagni 2010).

The interconnection of the three strategic pillars provides some coherence to the process of territorial development foreshadowed. Intelligent growth is based on improving education, achieving performance in research and technology transfer, thus being the engine of economic growth. Sustainable growth aims to increase competitiveness through efficient use of resources, especially nonrenewable, by accelerating the development of smart grids and strengthening the competitive advantage of European business environment. Sustainability will be the main product of such increases. The third pillar is inclusive growth so that every European citizen will have a job, will not be affected by poverty and will not feel discriminated. Only thus European resources can benefit to all regions, decreasing disparities and increasing territorial cohesion. On a more analyzed approach, it is clear that the first two pillars are the basis in achieving the third one; therefore we can not talk about inclusive growth, if do not have knowledge and necessary training and if resources are not used effectively divided.

Of the EU 2020 strategy there is notable the need to define localized policies and measures, the only ones able to eliminate long-term potential underutilization and reducing social exclusion. It is obvious that the key element in this strategy is the territory that has gained operational connotations, along with its transition from variables framework category to the dynamic variables, embedded in development. Cohesion policy, under all its aspects, integrates the 3 strategic pillars, projecting them in space.

Cohesion Policy 2014-2020 focuses on results by achieving territorial coherence and synergies and simplifying its implementation. Legislative architecture provides two regulations: one that defines the scope of the European Territorial Cooperation and the second one European Territorial Cooperation Group. This policy introduces some key changes in the wording of targets (which should be clear and measurable) and in terms of international and national legal 
framework. In addition, the terms and conditions of financing differ from the period of 20072013; there are several conditionings, that we find both ex-ante and ex-post. The first category ensures the European Union there are conditions necessary for the expected investment funds (in 2007-2013 lack of such conditionality has led, in some cases, to the inability to absorb a large part of the funds in European countries such as Romania), and the second one is designed to encourage and reward states that have fulfilled their objectives. Formally, this policy is correct, but not morally! There are at least some elements that have not been taken into account: all states are treated as being experienced in accessing and using European funds; different levels of development and the inability of states to incur expenditure, for which reimbursement is being made at a specific time, that can reach or exceed one year; lack of European financial means to help countries have access to such funds; the return of funds to the developed countries will have the opposite effect on territorial cohesion.

A positive aspect of the cohesion policy that is to be implemented is the importance given to local development, led by communities, with innovative financial means and with a leadership strategy. Obviously, there is not to be forgotten the monitoring and evaluation component, that should be undertaken along with the basic elements in order not to be considered at the end of the projects that they have not followed the procedures because of ignorance or malice.

In defining territorial cohesion policy for the next period a vital significance will have regions which are classified into three categories. Besides weak regions and developed ones, a new category is represented by transition regions which will have GDP/capita between $75 \%$ and $90 \%$ of EU-27 average.

At the same time, the online environment will be placed on a more important position in territorial development and often there will be talks about the "e-cohesion" for a better control of projects and expansion. Therefore, all member states should have by the end of 2014 suitable systems to allow recipients have access to all information in electronic format, not just printed.

Regarding EU funds, the European Regional Development Fund, which aims to reduce disparities between regions, will focus on sustainable urban development; mainly there will be required the development and adoption of a list of cities where integrated actions will be undertaken to promote sustainable development.

The truly innovative element within the cohesion policy for 2014-2020 is the mechanism to facilitate and encourage integrated operations through Integrated Territorial Investments (ITI). ITI is a tool through which an operation can be supported by several priority axes and programs can be linked together through an integrated investment strategy for a particular area or a particular functional area. This mechanism may take the form of an integrated urban development strategy, but can also support an interurban cooperation for specific projects of mutual interest. Action plans together with this tool facilitate the movement of funds to the local level in management and partnership, if local governments will insert them into their development strategies.

The third major reference document in territorial development is the Territorial Agenda 2020, approved during the Inter Ministerial Informal Meeting responsible with Territorial development planning spaces on May 19, 2011, in Godollo, Hungary. Within six territorial priorities for EU development, priorities defined in the document mentioned above, there are found many aspects reinforcing the idea of defining and implementing a territorial pact. Of these, there is to be noticed the priority to encourage integrated development of cities, rural specific areas. Cities are encouraged to look beyond their administrative limits, focus on regional functions and also 
to include in their projects peri-urban settlements, rural peripheral areas undeveloped and under-populated areas along with processes that disadvantage groups' segregation. With this priority, we foresee the existence and implementation of an expanded partnership, recognizing the interdependence between urban and rural areas. Managing these interdependencies and development process in such a framework can be possible only through integrated governance through partnership-based planning. Hence, the idea of redefining and reconsidering the concept of territorial pact as an integrator mean of regional policies aimed at achieving specific or global targets.

\section{Territorial Pacts - concept and adaptive approaches}

The Europe 2020 Strategy and Cohesion Policy talks about the Partnership Agreement, which is one of two major elements (along with Common Strategy Framework) of the programming period 2014-2020. It will replace the National Strategy Framework that will practically remain a starting point for further development of partnership agreements. This contract will be a joint document, a reference one that will require consistency, coherence and thematic focus, especially for Operational Programs, also being well defined and quite comprehensive in terms of national development programs.

One of the key positions of the Partnership Agreement aims the strategy for integrated approach to territorial development and the most affected regions in terms of poverty. It is desired for this document to be an effective coordination of policy instruments that impose a duty and commitment from both sides, both the member states and the European Union. This measure will be more difficult for member states to adopt because it requires a better coordination of policies than the National Strategy, but these contracts will be those that will initiate partnership commitments at national and regional level.

\section{Italian roots of territorial pact}

With this theoretical and instrumental support, Territorial Pacts are those on which current problems would apply, in order to change the approach to development issues and to define a new role for local initiatives. Analyzing various models at European level, it is clear that the Italian model of the so-called "patti territoriali" would be the correct tool for the situation in Romania, with some additional amendments. These "patti territoriali" opened new perspectives and launched a period of reforms for the Italian planning system, which, until then, the early 90 s, was based primarily on rational-comprehensive model of overlapping plans (from detail to territorial scale).

This system still represents the base for territorial and urban development in Italy, but it has been enriched with a number of tools and policies that allow the management of urban and regional problems. Also, the tools have worked at various levels. Territorial Pacts (1994-1997) realized strategies at a sub-regional level, but there were also implemented programs for the city and district (ie, "Contratti di Quartiere" - 1996). Also projects supported and developed by the European Union contributed greatly to territorial development (ie. Urban I and II). To all this was added a crucial factor, the gradual process of decentralization of the Italian system of government.

Territorial pacts can be analyzed from several perspectives. If we start from the definition according to which "a Territorial Pact for Europe 2020 is an agreement between the governmental levels of a country (local, regional, national), then the parties signing it undertake to coordinate and synchronize their political agendas to focus on objectives and targets of 2020 
Strategy through actions and financial resources ". In such a situation the national perspective is the one that prevails.

But what emerges from the existing documentation at European level is that these territorial pacts can play a vital role in territorial development through proper integration on several levels. It is a vertical, horizontal, conceptual, relational and functional integration that we should dwell upon, through a precise pact with an explicit partnership and a clear idea of development, in order to achieve coherence and cohesion of a region.

European experience, relatively limited in matters of territorial pacts, generally shows its dominance in inter-regional and local level. The idea of defining a national territorial pact as a tool for integrated territorial development is beneficial one, basing a type of strategy in which multistage association of local communities and socio-economic and cultural actors is the key of solving the common interest objectives.

The Committe of the Regions considers that in order to achieve the objectives in the EU 2020 Strategy, the Territorial Pact has to be promoted as a main tool to ensure territorial cohesion at a continental level. The territorial pact might be the link between the European Union Agenda, the national, regional and local programms correlated to the necessary resources to achieve the targets (Gill, Pereira and Teixeira 2010).

Territorial pact may be considered at national level as a significant document, with decisional effects only if it is able to coordinate, direct and produce integrated, consistent and sustainable territorial development. This is a tool through which territorial development strategies are implemented, promoting growth (as defined in Agenda 2020), by building partnerships between public and private actors.

A territorial pact should harmonize different territorial agendas of socio-economic actors, public administrations, at various levels, and other interested parties forming the partnership. Such a pact with national strategic territorial agenda at national level is correlated with the ones at lower levels: interregional, regional, county or local.

Territorial pact is closely related to a clearly defined territory, but also to a forced development idea for that territory. Partnership, public and private actors, along with identifying key or strategic projects, take over and implement the fundamental idea related to induction of territorial growth.

\section{Developing an adaptive approach}

By definition, the territorial pact, based on a realistic vision, will need to provide effective perspectives, policies and instruments at all main levels (national, regional, county, municipal) and intermediate individualized levels (urban areas, metropolitan areas, areas with a specificl thematic ones). In other words, the territorial pact as a tool can be considered a network of connected initiatives in certain territories, involving network shares placed on a multistage (from local to national level).

A first approach for territorial pacts focuses on the importance of spatial scale. Thus, the territorial pact is always associated with a regional or sub-regional scale (inter-county), being a tool that works in a transversal way cross the administrative boundaries, and negotiates solutions for territorial development, mediating through institutional powers or/and private interests. 
A second approach is the one taking into account their nature, aiming a specific target or another global one. Implementation of a territorial pact regarding integrated national development requires participation through cooperation of central actors in managing a network of territorial pacts. This management is based on the principle of negotiated programming, after which there are being financed projects proposed by regional, inter-regional, regional, county, local or inter-local pacts, after a preliminary assessment of applications. Vision of integrating these territorial pacts in networks and sub-networks contribute to an integrated development nationwide. These networks, subnets structured, include two categories of territorial pacts: sectoral (thematic) ones and global ones (Fig.1).

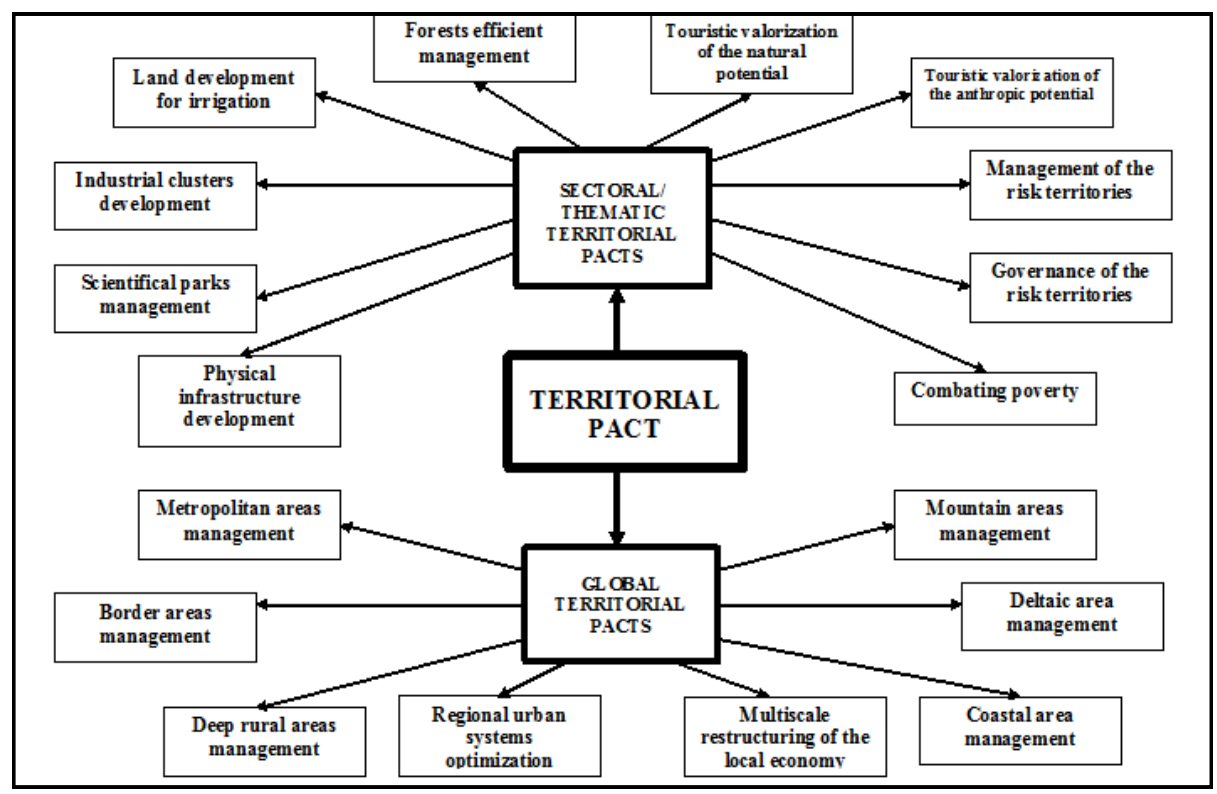

Fig.1 - Territorial pacts typology

Thematic territorial pacts are established by territorial actors at different levels to solve a problem faced by communities or achieve goals that integrate the projection of a coherent regional and national development. These territorial pacts are tools focused on achieving relatively punctual targets with effects in efficient structuring and planning functionality. Given the realities of the Romanian space, there can be individualized different thematic categories of territorial pacts, truly considered instruments in achieving the strategic objectives of territorial development in Romania. Among them, those that target the efficient management of some areas with different economic potential (touristic, agricultural, forestry) or of some protected areas, the industrial clusters development, the improvement of the territorial infrastructure or the control of some social phenomena with territorial projection.

Global pacts aim building partnerships between different actors and different levels of structure in order to boost sustainable management of different types of spaces. Targets are some focused on the development of the territories with a certain specific. Global territorial pacts are real territorial cohesion instruments and their implementation requires the existence of a flexible and very complex cooperation framework. As examples, specific for Romania, we can emphasize those that refer to different urban structures, to mountain or deltaic areas, to deep 
rural areas or transboundary areas.

\section{Conclusions}

Territorial pacts defined above may be accepted as toolkits in achieving an integrated national development, involving both these horizontal and vertical cooperation. Central bodies included in such territorial pacts can print them towards national strategic objectives; even if each is founded on a force idea emerged of each structure.

The passage from the gouverment to the gouvernance is a process where the key role is played by the territorial capital. Through the territorial gouvernance, there is a structuring process with an infinity of relationships between different actors, interested and non-conflictuals (Davoudi et al. 2008). The logic connexion is that the territorial pact is the most efficient sollution to achieve territorial gouvernance in order to increase territorial cohesion from a local level to the European Union level in its integrity.

National integrated development territorial pact, supported by a network of territorial pacts, is a necessity. Turning it into reality involves a clear definition, in a European and national context, of the concept of territorial pact, but also the one of network of territorial pacts, on the one hand, and implementation methods, on the other hand. Analyses undertaken by the pilot territorial pacts can contribute to learning more unknown items, especially regarding their territorial implementation. Multi-level governance, differentiated on 4 levels (local, regional, national and European) in Europe (Painter 2008) can be supported by the existence of some pacts from the same area, or by the cross-level pacts. Territorial pacts can be considered an example of collective action that can be permanently improved (Perri 2003).

Essentially, territorial pact is a commitment that can provide some legal resources with role in regulating relations between partners (private and institutional). In addition to other agreements on territorial development, it suggests forms of cross-border agreements and multi-scale, with variable geometry, which are essential to rethinking how to manage territorial development processes through intelligent, creative, sustainable and inclusive growth.

\section{Acknowledgements}

Partially, this article was written using some results achieved in the ESPON 2013 PROGRAMME, Project 2013/2/19 Growth Poles in South East Europe GROSEE.

\section{References}

AGNEW, J. (2001), "How many Europes? The European Union, eastward enlargement and uneven development", European Urban and Regional Studies, 8, 1, pp.29-38.

CAMAGNI, R. (2010), Territorial Cohesion: A Theoretical and Operational Definition, Scienze Regionali, 9, 1, pp.115-118. Athens.

CHRISTOFAKIS, M. (2001), Local development and Regional Policy, Papazisis,

CLERICI, M., A. (2004), Patti territoriali e sviluppo locale: alcune riflessioni a partire dai distretti industriali, Archivo di studi urbani e regionali, 80, pp.101-122.

DAVOUDI, S., EVANS, N., GOVERNA, F., SANTANGELO, M. (2008), Territorial Governance in the Making. Approaches, Methodologies, Practices, Boletín de la Asociación de Geógrafos Españoles, 46, pp. 33-52.

DE RITA, G., BONOMI, A. (1998), Manifesto per lo sviluppo locale: Dall'azione di 
comunita ai patti territoriali, Bollati Boringhieri, Torino.

ELISEI, P. (2012), The territorial Pacts, tools of regional and local development: from the Italian experience to the promotion of the Europe 2020 partnership, Urbanismul, 11, pp. 102-109.

FALUDI, A. (2009), "Territorial cohesion under the looking glass: synthesis paper about the history of the concept and policy background to territorial cohesion", European Commission, Regional Policy, Inforegio.

GIL, D., PEREIRA, M., TEIXEIRA J., A. (2011), The multi-scale approach of territorial cohesion: An analysis from the European Periphery, paper presented at the Conference "What future for cohesion policy? An academic and policy debate”, 16-18 March 2011, Bled, Slovenia, Accessed at January 14 2013, in http://www.regional-studies-assoc.ac.uk/events/2011/marslovenia/papers/Gil.pdf.

GROSJEAN, N., CREVOISIER, O. (2003), Autonomie differenciée des systèms de production territoriaux. Revue d'Ėconomie Régionale et Urbaine, ADICUEER, 2, pp. 291-315.

HADJIMICHALIS, C. (2011), Uneven geographical development and socio-spatial justice and solidarity: European regions after the 2009 financial crisis, European Urban and Regional Studies, 18, 3, pp. 254-274.

HARVEY, D. (2010), The Enigma of Capital: And the Crises of Capitalism, Profile Books, London.

IANOS,, I. (2012), European Territorial Cohesion, between reality and imagination, paper presented at the The Second Romanian - Bulgarian - Hungarian - Serbian Conference "Geographical Research and Cross-Border Cooperation within the Lower Basin of the Danube", Eger, Hungary, September 20-23, 2012.

JONES, M., JESSOP, B. (2010), Thinking State/Space Incompossibly, Antipode, 42, 5, pp. 1119-1149.

KIS, E. (2011), The impacts of the economic crisis on the spatial organization of Hungarian industry, European Urban and Regional Studies, 19, 1, pp. 62-76.

KULCSAR, L. (2003), Territorial Policy during the Post-Socialist Period in Hungary, Eastern European Countryside, 9, pp. 145-158.

MEDEIROS, E. (2012), Territorial Cohesion: a conceptual analysis, Centre de Estudos Geograficos (CEG) - Institute of Geography and Spatial Planning (IGOT), Lisbon University, Accessed at December 15, 2012 in http://ww3.fl.ul.pt/pessoais/EduardoMedeiros/docs/ PUB_PAP_EM_Territorial_Cohesion.pdf.

PAINTER, J. (2008), European Citizenship and the Regions, European Urban and Regional Studies, 15, 5, pp. 5-19.

PERRI, A. (2003), II patto territorial della Locride, in: La Lezione dei patti territorili, Ministero dell'Economia e delle Finanze, Dipartimento per le Politiche di Sviluppo, Gennaio, pp. 429-459.

PICCHIERI, A. (2002), La regolazione dei sistemi locali, II Mulino, Bologna.

UZUNOV, F., V. (2012), State regulation as a factor in creating favorable conditions for economic activity of corporate enterprises within regions, Actual Problems of Economics, 12, 138, pp. 95-105.

Initial submission: 16.08 .2012

Last revised submission: 22.03.2013

Final acceptance: 31.05.2013

Correspondence: University of Bucharest, Interdisciplinary Centre for Advanced Research on Territorial Dynamics, 4-12, Regina Elisabeta Blv., 030018, Bucharest, Romania

E-mail: irinasaghin@gmail.com 
